\title{
A reader-response approach \\ to Matthew 24:3-28
}

\author{
W S Vorster \\ University of South Africa
}

\begin{abstract}
It is assumed that reading is an interactive process between a text and a reader. Attention is paid to how Matthew 24:3-28 evokes a reader's response and what strategies readers apply as they read the text.
\end{abstract}

By this time it is common knowledge among New Testament scholars that the reader plays an active role in assigning meaning to a text. The reception of Matthew 24 makes it clear that this text has prompted readers to assign different, even contradictory, interpretations to the text or to parts of it. It is interesting to page through commentaries, articles and translations to see what scholars say the text is about. Captions such as 'Discourse on the last things' (M'Neile 1957:343), 'Endzeitrede: Das Kommen des Weltrichters' (Schweizer 1973:293), 'Prophecies and warnings' $(N E B)$, 'The testament of Jesus-Sophia' (Burnett 1981) and 'The Matthean apocalypse' (Brown 1979), reveal how different readers describe the 'substantive content' (Lafargue 1988) of Matthew 24 (see also Kloppenborg 1979 and Köhler 1987 for early receptions of the text). Since reading is more than the discovery of the meaning which is seemingly inscribed into a text, it is not strange that different readers, who are themselves semiotic topics (see Vorster 1989a:60-61), interact with the text and actualise its meaning potential differently.

This essay is based on the assumption that reading is an interactive process between a text and a reader. It is furthermore assumed that texts do not have meaning. Meaning is arrived at by the dialectical process between a text, which evokes a response from the reader, and the reader who assigns meaning to the text, or responds to the text. It is also assumed that the (implied) reader is inscribed into the the text and that a real reader has a role in creating meaning by responding to codes

- This essay is a reworking of a paper which was originally presented at the meeting of the subgroup on Matthew during the 1991 meeting of the Societas Novi Testamenti Studionum in Bethel, Germany. Financial assist ance by the HSRC to attend the meeting is hereby acknowledged. 
inscribed into the text (see Vorster 1989b; also Anderson 1983; Burnett 1990; Phillips 1990). The essay therefore deals with what the text does to the reader, and how the reader responds to the text. Attention will be paid to how Matthew 24:3-28 evokes a reader's response and what strategies the readers apply as they read the text. Since I was invited to approach the text from a reader-response perspective, I have chosen the title accordingly. I have, however, taken the liberty not to restrict myself to a specific form of reader-response criticism. The essay is based on reception theory in general (see Lategan 1984:10ff; also Porter 1990). Special attention will be paid to the question of whether the speech deals with the fall of Jerusalem or with the return of the Son of man. With this in mind, matters such as the function of the use of the futurum, the conjunction yáp, the motif of alertness, and defamiliarisation are treated.

\section{ON READING MATTHEW 24:3-28}

Matthew 24:3-28 forms a very small fragment of the Gospel as a whole, and also only a fragment of the speech of Jesus in Matthew 24-25. From the perspective of this essay it is, however, impossible to read these few verses without being informed by the preceding material, and also by what follows (see Howell 1990). A few preliminary remarks are therefore in order.

The material preceding Matthew 24 is important because it 'constitutes the reader's "education"'(Burnett 1985:92). By a variety of codes and strategies the reader is equipped to read later parts of the text.

Reading concerns the process of interaction with the text. Each word, sentence, event or character creates certain expectations which are either fulfilled or disappointed in the reading process. The reader therefore engages in forming expectations and revising these expectations by reading the text sequentially and by processing the information. By the time the reader of Matthew's Gospel reaches chapter 24 , he/she is well informed about the characters, events and standards of judgement.

Matthew 24:3-28 forms part of Matthew 24:4-25:46, one of five major narrated (see Vorster 1987) speeches of Jesus in the Gospel (chapters 5-7; 10; 13; 18; 24-25). At this stage the reader not only knows that Jesus is the most important character in the story but also that, unlike the Pharisees or even the disciples, he is a reliable character. Like the narrator of the story, he is omniscient. He knows what other characters feel, think and plan. It is also known that whenever he speaks important information is given to the reader, and that he presents the 'viewpoint of God' (Mt 16:23; see also Kingsbury 1986:32ff). 
Burnett (1985; see also Van Aarde 1982) has convincingly shown that when the reader reaches chapter 24 , he/she knows that whenever Jesus appears, he is 'God with us', and that he is revealing the 'plan of God'. The reader also knows that he will most probably be revealing an important message to the disciples, and therefore to the readers of the Gospel in 24:3-28. On different occasions in the preceding material he instructs his disciples and reveals to them his point of view $(5: 1 ; 13: 10$, $36 ; 15: 12$ and 18:1). Simply from the redundant information that is given by the text, the reader knows certain things which might be expected. The phrase kaOnuévor

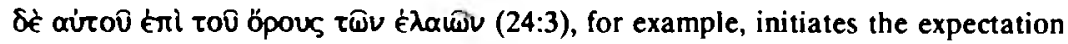
that Jesus will authoritatively reveal something, because the reader is educated that whenever Jesus sits, he teaches with authority (see 5:1-2; 13:1-3 and 15:29). It is also known that the 'mountain' (see Donaldson 1985) is a place of revelation in the Gospel (see $5: 1 ; 28: 16$; also $8: 1 ; 14: 23 ; 15: 29 ; 17: 1,9 ; 26: 30$ ).

The fact that the disciples approach Jesus is also not without significance. They are his immediate followers, to whom he reveals the plan of God. The reader is expected to identify with his message to them.

It is, however, not only the information that precedes chapter 24:3-28 that is important to the reader. What follows similarly determines the response of the reader to the text. In fact, in the process of reading the reader has to revise, for instance, the idea that the proclamation of the message is restricted to the Jews only as it is said in chapter 10 . In different ways, as we shall see, the reader is re-educated by the story. In short, the text does something to the reader. It directs the reader and initiates certain responses.

\section{ON PROMPTTNG THE READER IN MATTHEW 24:3-28}

If one wants to know how Matthew 24:3-28 evokes a response from the reader, one has to address the following question rigorously: what do the words, the sentences, the sections of the text, and the speeches of Jesus do? Not simply what the text means, or what it refers to. The focus is thus not only on what is said, but also why it is said. In this way one is able to determine the purpose of what is narrated in Matthew 24.

One should keep in mind that people do things with words. When asked a question, for instance, the hearer or reader is prompted to formulate an answer or to perform a deed. A prohibition urges the hearer not to do a certain thing, and a warning advises a person to take care. Forms of speech like sentences, questions and so on are therefore not only concerned with what they say, but also with their purpose or with what they do. By saying something, the speaker performs an act 
(see e g Bach \& Harnish 1979). This also holds true for the words and sentences in the story of Matthew.

The narrated speech of Jesus in Matthew 24 is introduced by a description of a new setting and a request by the disciples (24:3). There is a change of scene, but is there a change of topic? And what did the narrator of the story do with these words?

The preceding section (23:34-24:2) deals with the rejection and judgement of Jerusalem and her leaders and the prediction of the destruction of the temple. It has been argued on many and different grounds by scholars that the speech of Jesus in chapters 24-25 is a continuation of the theme of the destruction of the temple. The repetition of ravra in verses 2 and 3 has led many interpreters to conclude that the question of the disciples, 'when will these things be?' refers to the destruction of the temple, and that Matthew 24:4-50 gives an answer to the question. Does it? It will only be possible to answer this question after we have dealt with the content of the speech.

Once the reader has learnt that Jesus is a reliable character, he/she has no problem with Jesus being able to speak about future things and make predictions. In fact, this has often occurred in the preceding parts of the story. In terms of narrated and discourse time ('erzählte und besprochene Welt'), it immediately becomes evident that there is a change in the use of tenses in Jesus' speech. Most of the verbs are put in the future and present tenses, which are typical of the tenses used for discussing matters. It is also characteristic of the future tense, especially in predictions and assertions, that they express the belief of the speaker and his or her desire that 'the hearer have or form a like belief' (see Bach and Harnish 1979:41). It is therefore possible to infer from the use of tenses in Matthew 24:3-28 that the Matthean Jesus wishes his disciples to share his beliefs about the future. He performs a speech act by what he communicates. To put it differently: the text (of the Matthean Jesus) prompts a response from the disciples.

On the level of the reader of the Gospel of Matthew the same thing happens. Having presented Jesus as the reliable character who now speaks about future things, the narrator also expects the reader to share Jesus' beliefs about the future.

It is, however, important to pursue this matter further. The speech starts with

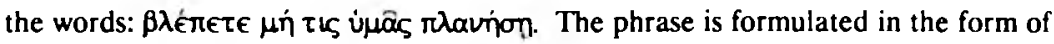
a prohibition. Prohibitions, like all other linguistic directives such as questions, requirements and so on, 'express the speaker's attitude toward some prospective action by the hearer' (Bach \& Harnisch 1979:41). The force (purpose) of the phrase is to warn the reader not to be led astray. In other words, what the phrase does is to direct the reader to take a certain action, that is, to be on the alert. It does not so 
much inform the reader as it instigates an action. The same happens in verses 6,14 , $15,16,17,18,20,23$ and 26 , where prohibitions and requirements are mentioned. The disciples are warned to be on the alert, not to be troubled or disturbed, to witness, to be conscious of the times in which they live, to take preventive action, to pray and not to be misled.

If one carefully investigates the different directives referred to in the speech, it becomes clear that they structure the speech. This happens to such an extent that the main thrust of the speech comprises an appeal to the reader to maintain a state of alertness, and to await the return of the Son of man faithfully. From the perspective of what the text does it can be argued that it directs the reader to adopt a particular attitude, that is, to be on the alert, take heed and be warned. This view is undergirded by the way in which the prohibitions and commands are substantiated.

The use of the conjunction yóp in the Gospel of Matthew reveals many interesting features with regard to its narrative function (see Edwards 1990). It is evident that the reliability of references to the future in any discourse mainly depends on the authority and reliability of the speaker. Jesus is the appropriate character in Matthew's Gospel to make statements about the future, since he is presented as a wholly reliable character. His reliability is already established in the so-called framework of the Gospel (1-4:22) by different yóp-clauses used by different characters (see Edwards 1990:642-646, 652). The effect of these statements is to show the reader that the events referred to are part of the divine plan of God, and that 'the reader should expect God's control over events whether it is explicitly stated or not' (Edwards 1990:642).

It is furthermore remarkable that this conjunction yop often occurs in the sayings of Jesus which reveal his assumptions. They form part of his narrative point of view, which is presented as the viewpoint of God.

In Matthew 24:3-28 yóp is used no less than six times as part of Jesus' directives to the disciples $(5,6,7,21,24,27)$. These $\gamma$ óp-clauses predict the appearance of false messiahs, the delay of the final consummation, the advent of wars, famines and earthquakes, and the sudden return of the Son of man. All of these clauses, which are in the form of predictions, substantiate preceding commands. Their effect is that the reader has to be on the alert because the return of the Son of man will be preceded by horrifying events. In one case (v6), the theme of God's plan, which plays an important role in the narrative from the start, is called to mind and used as

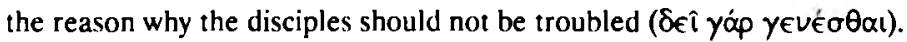

The effect of the directives that Jesus gives to the disciples is moreover

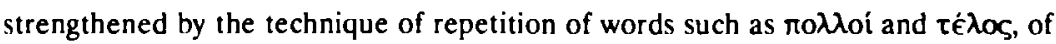
negative events, and of themes such as false messiahs. 
It is evident from the speech acts performed in this speech that Jesus wished his disciples to believe that they could expect a turbulent future. Although he phrased his statements in general (apocalyptic) form, they nevertheless convey the idea of difficult times awaiting the hearer before the return of the Son of man. Even the reference to tò $\beta \delta \delta^{\prime} \lambda u y \mu \alpha$ tîs épquúvews from the Book of Daniel (Mt 24:15), and the references to the flight to the mountains of Judea (Mt 24:16) should not be interpreted primarily in terms of historical references in the time of the disciples or the author of the Gospel. These signs form part of the narrated world which portrays difficult times of persecution and misery. They all help to impress the disciples/readers with the difficulties which will precede the return of the Son of man. What is, however, important to realise is the observation that the effect of the directives in the speech is to keep the listeners on their toes. They have to be on the alert and live with a view to the return of the Son of man. There is an urgent appeal for them to take care. As a narrated speech the material also has to be read on the level of the reader, and not only on the level of the disciples as hearers. The speech acts serve the same purpose on this level that they do on the level of the disciples. The reader receives the same instructions since he/she is inscribed in the text. This

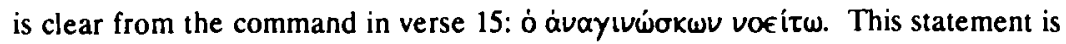
very important with regard to the response of the reader, since it determines the location of the reader of the Gospel of Matthew (see also Mt 27:8; 28:15).

The reader of the Gospel finds him/herself in the period after the resurrection and before the return of the Son of man. This is evident from the fact that the text refers to a reader outside the text of the Gospel in which the resurrection is narrated. 'He who reads' the speech, refers to the reader of the Gospel. This also helps the reader to decide whether this speech of Jesus is about the destruction of Jerusalem or about the return of the Son of man.

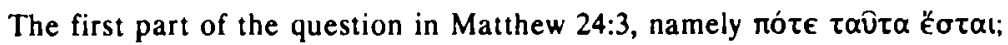
might have led the reader to wonder whether the speech would deal with both the destruction of Jerusalem and the return of the Son of man. The interpretation of this part of the question has been a bone of contention among interpreters of the Gospel for many years. Different solutions have been offered to explain the apparently ambiguous question (see Burnett 1981:8ff and especially 198ff). Let us first turn to the 'substantive content' of the speech again. A few remarks on the 'return of the Son of man' are necessary.

Although rapovoi $\alpha$ can obviously be used for the meaning 'to be present', it is improbable that this is the case in Matthew 24:3. The disciples clearly want to be informed about the return of the Son of man and the end of the age. The term rapovoia occurs five times in the Gospel, and only in chapter 24 ( $v 3,27,30,37,39$ ). 
Considering the specificity of the question ti to onueiou tńs rapovoias; and the fact that the Matthean Jesus refers to the return of the Son of man three times in the speech, there seems to be little reason to doubt that Jesus' speech gives an answer to the question. Although verse 30 refers only to the sign of the Son of man, and not to his return, the reader would undoubtedly understand this sign in conjunction with verse 27 . The 'return' is, in other words, implied in verse 30 . The return of the Son of man is a formative principle in the speech.

It is furthermore evident that 'Son of man' refers to Jesus. Because the reader has been educated by the preceding material in the Gospel that 'Son of man' is another name for Jesus (see 8:20; 9:6 etc), and even that he will return some time in the future as the Son of man (10:23) and as judge (13:41), the reader knows that the Son of man in chapter 24 is Jesus. The reader also knows that the speech is first of all an answer to the question about the return of Jesus. The third part of the question of the disciples concerning the end of the age is answered indirectly in Matthew 24:3-28, and more fully in chapter 25 . But what about the first part, 'When will these things happen?'

Burnett (1981:206) and others have argued that there is a caesura between 24:2 and 3 and, following Walker, that the kai between the first and second parts of the question should be read epexegetically: 'Tell us, when will this happen, that is (kai), what will be the sign of your Parousia and the consummation of the Age?' (Walker as quoted by Burnett 1981:207). This is a possible solution to the problem, and the conjecture of a caesura explains the break between $24: 2$ and 3 . However, from a reader-response perspective, it seems to me that the speaker (Jesus) flouts the question of the disciples, and indicates that he does not want to pursue the topic of the destruction of Jerusalem and the temple any further. He breaks the maxim of relevance in the disciples' question and pursues the matters posed in the second and third parts of the question (see Botha 1989:158 for a discussion of the principle). The disciples are furthermore defamiliarised - that is, put into a different perspective from the one the reader is used to - a strategy which is common in the synoptic gospels (see Resseguie 1984) and which also plays a role in Matthew 24.

Chapter 23 has educated the reader that Jesus has rejected Israel, in particular Jerusalem, and that he has predicted the destruction of the temple. The latter is dealt with briefly in verse 2 . Because of the repetition of the pronoun toûta in verses 2 and 3, it is quite natural that the reader would expect Jesus to continue with the theme in his answer to the disciples. By the end of the speech the attentive reader would realise that Jesus has defamiliarised the familiar by speaking about his return and the end of the age and not about the destruction of the temple. $\mathrm{He} / \mathrm{she}$ will then revise the question and realise that Jesus does not fulfil the expectation by 
ignoring the question. For the (implied) reader of the Gospel, who probably lived in a period after the destruction of the temple, and who might have been familiar with the destruction of the temple and Jerusalem, this defamiliarisation creates the opportunity of seeing the novelty in the story of Jesus.

There are other examples of defamiliarisation in Matthew 24 which are equally important. It is often argued that there is a contradiction between Matthew 10:5 and 23 on the one hand and $24: 15$ on the other (see also 28:19). It is thought that in Matthew 10 the focus is still on the exclusivity of the mission of the disciples to Israel, and that this presents a different view from later material, where the good news of the man of Nazareth is understood in universal terms. From the perspective of the reader of the Gospel, he/she is educated by the story that, in chapter 10 , the disciples were ordered to go and proclaim the message to Israel only. But, as the story develops, it is also learnt that Israel is rejected. When the reader reaches $24: 15$, the familiar is completely defamiliarised. A new message is given by rephrasing familiar material. Since Israel has rejected the proclamation of the message (see Mt 23), the proclamation would be directed to all the nations.

Another example of defamiliarisation is the fact that no definite answer is given of exactly when the return will be. Since the reader knows that Jesus is a reliable character, it would seem obvious that he/she would also know when the return of the Son of man will be, and when the age will end. However, the disciples (and therefore the readers as well) are told that they should faithfully await the coming of the Son of man. Not even the Son knows the exact time $(24: 36)$. The expectation of the disciples/readers is disappointed, and instead they receive a very definite injunction: be on the alert!

\section{0}

Reader-response criticism does not offer answers to all the questions that are raised by ancient texts such as the Gospel of Matthew, not to mention the difficulties involved in such a complicated text as Matthew 24. Since the emphasis is on the reader, and how a text elicits a response from the reader, aspects of the communication between texts and readers/hearers are highlighted. With its focus on what texts do, and not only on what they mean, a neglected aspect of textual interpretation in New Testament scholarship receives attention. It has been illustrated that Matthew 24 directs the reader to read this part of the Gospel in the light of earlier parts, and that the speech acts used in the text help the reader to build an image of what the text does. It is in this way that a contribution is made to the interpretation of this very difficult early Christian text. Since the essay offers a discussion of a fragment 
of a fragment of a text, it is obviously incomplete. The aim, however, has been to illustrate how focusing on what the text does to evoke the response of the reader, and how the reader responds to the text, helps one to understand Matthew 24:3-28. Because of a lack of space, no attention has been paid to the detailed interpretation of every word or sentence, or to genre and other difficulties. The use of technical jargon has been limited to a few expressions. The informed reader will nevertheless recognise that the essay has been based, among other things, on insights from narrative, reception and speech act theories.

\section{Works cited}

Anderson, J A 1983. Matthew: Gender and reading. Semeia 28, 3-27.

Bach, K \& Harnish, R M 1979. Linguistic communication and speech acts. Cambridge: MIT.

Botha, J E 1989. A study in Johannine style: History, theory and practice. DTh thesis, University of South Africa, Pretoria.

Brown, S 1979. The Matthean apocalypse. JSNT 4, 2-27.

Burnett, F W 1981. The testament of Jesus-Sophia: A redaction-critical study of the eschatological discourse in Matthew. Lanham: University Press of America.

--- 1985. Prolegomenon to reading Matthew's eschatological discourse: Redundancy and the education of the reader in Matthew. Semeia 31, 91-109.

--- 1990. Postmodern biblical exegesis: The eve of historical criticism. Semeia 51, 51-80.

Donaldson, T L 1985. Jesus on the mountain: A study in Matthean theology. Sheffieid: JSOT.

Edwards, R A 1990. Narrative implications of gar in Matthew. $C B Q$ 52,636-655.

Howell, D B 1990. Matthew's inclusive story: A study in the narrative rhetoric of the first Gospel. Sheffield: JSOT.

Kingsbury, J D 1986. Matthew as story. Fortress: Philadelphia.

Kloppenborg, J S 1979. Didache $16^{6-8}$ and special Matthean tradition. ZNW 70, 54 67.

Köhler, W-D 1987. Die Rezeption des Matthäusevangeliums in der Zeit vor Irenäus. Tübingen: Mohr.

Lafargue, M 1988. Are texts determinate? Derrida, Barth, and the role of the biblical scholar. HTR 3, 341-357.

Lategan, B C 1984. Current issues in the hermeneutical debate. Neotestamentica 18, 1-17. 
M'Neile, A H 1957. The Gospel according to St. Matthew: The Greek text with introduction, notes, and indices. New York: Macmillan.

Phillips, G A 1990. Exegesis as critical praxis: Reclaiming history and text from a postmodern perspective. Semeia 51, 7-49.

Porter, S E 1990. Why hasn't reader-response criticism caught on in New Testament studies? Journal of literature \& theory 4, 278-292.

Resseguie, J L 1984. Reader-response criticism and the synoptic gospels. JAAR 52, 307-324.

Schweizer, E 1973. Das Evangelium nach Matthäus. Göttingen: Vandenhoeck.

Van Aarde, A G 1982. God met ons: Dié teologiese perspektief van die Matteusevangelie. DD thesis, University of Pretoria, Pretoria.

Vorster, W S 1987. Literary reflections on Mark 13:5-37: A narrated speech of Jesus. Neotestamentica 21, 203-224.

--- 1989a. The in/compatibility of methods and strategies in reading or interpreting the Old Testament. Old Testament Essays 2, 53-63.

--- 1989b. The reader in the text: Narrative material. Semeia 48, 21-39. 